\title{
The Influence of Entrepreneurship Education on The Business Performance Through Entrepreneurial Intention
}

\author{
Sabrina Amaliawati ${ }^{1}$, Trisno Martono ${ }^{2}$, Cicilia Dyah Sulistyaningrum Indrawati ${ }^{3}$
}

\begin{tabular}{l} 
ARTICLE INFO \\
\hline Article History: \\
Received 03.10.2018 \\
Received in revised form \\
29.12 .2018 \\
Accepted \\
Available online 01.04 .2019
\end{tabular}

\begin{abstract}
The research was conducted at MSMEs Batik KampungLaweyan, Surakarta City, Central Java Province, Indonesia. Problems that occur in MSMEs Batik Lawey an is a decrease in sales turnover and some MSMEs bankruptcy. This research aims to determine the influence of entrepreneurship education on business performance through entrepreneurial intentions. The method used is descriptive method with a survey approach. The number of respondents in this research were 67 MSMEs owners. Testing the hypothesis in this research using PLS-SEM analysis with the help of software SmartPLS 3.0. The results showed (a) entrepreneurial education has a positive and signific ant influence on entre preneurial intentions (orig inal sample $0.276 \& t-v$ alue $2.136>1.96$ ), (b) entrepreneurial education has a positive and signific ant influence on business performance (orginal sample 0.235 \& t-value 2,960> 1.96), (c) entrepreneurial intention has a positive and significant influence on business performance (orginal sample $0.323 \& \mathrm{t}$-value 1.96), (d) entrepreneurial education has an indirect influence on business performance through entrepreneurial intentions (the values of indirect influence is 0.089 ).
\end{abstract}

(C) IJERE. All rights reserved

Keywords:

Entrepreneurship education, entrepreneurial intention, business performance.

\section{INTRODUCTION}

MSMEs is micro, small and medium enterprises that have a turnover below Rp 1 billion. Criteria MSMEs has been confirmed and regulated by the Government through Law No. 20 of 2008. MSMEs is the productive business opportunity of an individual or a business entity that meets the criteria as stipulated by the Law. MSMEs plays a role in grow th and job creation (Gibb and Li, 2003; Tether and Storey, 1998). Law Number 20 of 2008 Chapter III Article V explains that the role of MSMEs is to help build the regional economy, create jobs, equalize income, economic growth and alleviate people from poverty. The performance of small and medium enterprises is the main sector of economic growth in developed and developing countries (Lumpkin and Dess, 1996; Wiklnd and Shepherd, 2005). Based on the role of MSMEs on the economy, research on the business performance of MSMEs entrepreneurs is interesting to study. Business performance is the achievement of a person or copany in achieving a goal. Maximum performance is the main hope of the bussines unit in carrying out its business. Accroding to Mulyadi (2007) business performance is the success of personnel, teams or organization unit in realizing previously set strategic target. Many opinions regarding factors that can affect business performance, one of which is Entrepreneurship Education.

Entrepreneurship education is a planned effort to improve skills and knowledge in entrepreneurship. Entrepreneurship education not only provides a theoretical basis for the concept of entrepreneurship but also shapes the attitude and the mindset of an entrepreneur. Entrepreneurship education can be given in various levels of education, starting from the basic education level to the level of secondary education in a sustainable and integrated manner (Rina, Murtini and Indriayu, 2018). According to Enu (2012) entreprenership education is a form of entrepreneurship education that has the aim of providing knowledge, skill, attitudes and motivation to individuals succed in entrepreneurship. The presence of successful entrepreneurs and the number of entrepreneurs in the community depends on prospective entrepreneurs who receive entrepreneurship education and have a desire to become entrepreneurs (Dogan, 2015). Through entrepreneurship education MSMEs will get the provision to work professionally in work planning, management and evaluation. Sufficient entrepreneurship education will provide the skill and knowledge needed by an entrepreneur to build and develop a business (Paco, Fereria, Raposo and Radriges, 2015). According Chilliya (2012) the entrepreneurship education received will have significant impact on the production of the business undertaken. Although entrepreneurship education received by individuals can help in carrying out their business, it does not nessarilyguartantee that the

1brina271293@gmail.com, SebelasMaret University, orcid.org/0000-0002-8123-7258 
business. In addition to skills and knowledge, high entrepreneurial intentions are need to maintan business performance.

Intention is a desire that arises in a person without any compulsion from others to take action. Entrepreneurial intention directs one;s action by connecting the considerations that are believed and disered. Through entrepreneurship education will also encourage entrepreneurial intentions of business people (Hattab, 2014; Franke and Luthje, 2004). Radhipere and Ladzoni (2014) states that entrepreneurial intention is classified as the most powerful indicator of business performance. The stronger the intention in a particular behavior, such as choosing a carrer path as an entrepreneur, the more positive the behavior performance will be (Farrington, Venter, and Neethling, 2012). Entrepreneurial intentions of a person are influenced by entrepreneurship education that he receives. Entrepreneurial education has a role in encouraging one's entrepreneurial intentions (Hattab, 2014; Franke and Lutjhe 2014). Less education will lead low levels of entrepreneurial intentions (Franke and Lutjhe, 2014). According to Silvia (2013) who sated that someone who obtained entrepreneurship education has a higher intention than those who did not get entrepreneurship educations.

Entrepreneurship education has an influence on entrepreneurial intentions as stated by previous researchers. How ever, there is another opinion which states that entrepreneurship education has no relationship to the intention of entrepreneurship. According to (Cheng, Chan \& Mahmood, 2009) states that entrepreneurship education does not have a significant relationship to entrepreneurial intentions, this is because the process of delivering entrepreneurship education is less effective.In addition, Dogan (2015) also stated that what can change the traits of one's entrepreneurship is not what they learn about entrepreneurship, but what they learn about themselves and their abilities.

This research was conducted at MSMEs Batik Laweyan Surakarta, Central Java, Indonesia. Kampung Batik Law eyan is the largest center of batik production in Surakarta City which has an attraction. The appeal of the Kampung Batik Law eyan includes socio-economic conditions, cultural heritage conditions and batik industry conditions. As the central ruler of the biggest batik in Surakarta city, the MSMEs Batik Law ey an is a driver of economic grow th in Surakarta City. The highest number of MSMs in Surakarta City is in Law eyan, thus encouraging the researcher to conduct research at MSMEs Batik Law eyan.

\section{Situation of the Problem}

Based on research conducted by author in September 2018, the MSMEs Batik Laweyan has experienced several problems related to the performance of MSMEs owners. The problem that the issue is decrease in sales turnover and the are several MSMEs that experience bankruptcy. This is due to several other factors: (a) less qualified and professional human resources, (b) bookkeeping that has not been arranged neatly and regularly, (c) calculation of production coast that are still based on estimates, (d) business people who lack entrepreneurial spirit.

\section{The aim of the Study}

The purpose of this study was to determine the relationship between the variables studied. The objectives are as follows:

1. Knowing the influence of entrepreneurship education on entrepreneurial intentions.

2. Knowing the influence of entrepreneurship education on business performance.

3. Knowing the influence of entrepreneurial intentions on business performance.

4. Knowing the influence of entrepreneurship education on business performance trough entrepreneurial intentions.

\section{METHOD}

This research was conducted at MSMEs Kampung Batik Laweyan, Surakarta city, Central Java Province, Indonesia. The target in this study was MSMEs Batik. Selected MSMEs is Batik Kampung Laweyan because the highest number of MSMEs in Surakarta is here. The population in this study were 67 respondents so that all respondents were taken as samples because the population was less than 100 . The identity that must be filled out by the respondents in the questionnaire includes the name, gender and level 
of education. The proportion of respondents by gender can be seen in table 1 and the proportion of respondents based on education level can be seen in table 2 .

Table 1 Respondents by gender

\begin{tabular}{|c|c|c|c|c|}
\hline \multirow[b]{2}{*}{ der } & Gen & \multirow[t]{2}{*}{ Freque } & & \multirow[t]{2}{*}{ Precen } \\
\hline & ncy & & tage & \\
\hline & \multirow[t]{2}{*}{ Male } & 51 & & 76,11 \\
\hline & & & $\%$ & \\
\hline & \multirow[t]{2}{*}{ Fem } & 16 & & 23,88 \\
\hline ale & & & $\%$ & \\
\hline
\end{tabular}

Source : data processed, 2018.

Based on table 1, it can be seen that male respondents are around $76.11 \%$ and women are around $23.88 \%$. This means that there are more male MSMEs owners than women.

Table 2 Responden by level of education

\begin{tabular}{|c|c|c|}
\hline $\begin{array}{rr}\text { Level } & \text { of } \\
\text { Education } & \end{array}$ & $\begin{array}{ll} & \text { Frequenc } \\
y & \end{array}$ & Precentage \\
\hline High School & 37 & $55,22 \%$ \\
\hline Diploma III & 5 & $7,46 \%$ \\
\hline S1 & 22 & $32,83 \%$ \\
\hline S2 & 2 & $2,98 \%$ \\
\hline S3 & 1 & $1,49 \%$ \\
\hline
\end{tabular}

Source : data processed, 2018

Based on Table 2, it can be seen that the highest education level of respondents is high school around $57.22 \%$. This means that the lev el of education most of the MSMEs owners have is high school.

This study used a survey method that aims to determine the relationship between variables of entrepreneurial education (exogenous), entrepreneurial intentions (mediation) and business performance (endogenous). Table Table 3 is a simple description of the variables in this study as follows:

Table 3. Range of Research Variables

\begin{tabular}{|c|c|c|}
\hline Variable type & Variable & Dimension \\
\hline $\begin{array}{l}\text { Exogenous } \\
\text { Variable }\end{array}$ & $\begin{array}{l}\text { Entre preneurship } \\
\text { Education }(\mathrm{X})\end{array}$ & $\begin{array}{l}\text { (a) Formal Education (b) Non-formal education (c) } \\
\text { Informal Education }\end{array}$ \\
\hline $\begin{array}{l}\text { Mediation } \\
\text { Variable }\end{array}$ & $\begin{array}{l}\text { Entre preneurial } \\
\text { Intentions }(Z)\end{array}$ & $\begin{array}{l}\text { (a) Glad entrepreneurship (b) Want to have a higher } \\
\text { income } \\
\text { (c) Want to be able to manage time and himself (d) Want } \\
\text { to create jobs for other people. }\end{array}$ \\
\hline $\begin{array}{l}\text { Endosenous } \\
\text { Variable }\end{array}$ & $\begin{array}{c}\text { Business } \\
\text { Performance }(\mathrm{Y})\end{array}$ & $\begin{array}{l}\text { (a) Profit growth (b) Growth in the number of customers } \\
\text { (c) Growth in the number of sales (d) Growth in the } \\
\text { number of assets }\end{array}$ \\
\hline
\end{tabular}

Sources : Sujanto, 2009; Law Number 20 of 2003; Manan, Sanusi and Samiadji, 2014; Tarmudji, 2006; Riyanti, 2003; Yuw ono, 2008; Mudjiarto, 2005; Zimmerer, 2004; Zaenal, 2012. 


\section{Material}

Data collection in this study used interviews, documentation and questionnaires. Interviews a re conducted to obtain detailed and in-depth information about the object of research. Interviews in this study were conducted between researchers and owners of MSMEs Batik Laweyan as selected respondents. Documentation was carried out to obtain data by looking at existing documents to strengthen the data obtained, in this study the data were in the form of the number of MSMEs Batik Laweyan owners and photos of activities in the MSMEs. Questionnaires are conducted by providing a set of questions or statements to the respondent. In this study, the questionnaire w as closed so that respondents could answer the questions or statements that had been provided by the researcher. The questionnaire in this study used a Likert scale. The statement in this study consisted of positive statements and negative statements. The answer consists of 4 answer choices namely Strongly Agree (S), Agree (S), Disagree (TS), and Strongly Disagree (STS).

Table 4. Respondents Answer Value

\begin{tabular}{|c|c|c|c|c|c|}
\hline Positive Statement & & & Negative Statement & & \\
\hline The Answer & Code & Value & The Answer & Code & Value \\
\hline \multirow[t]{2}{*}{ Strongly Agree } & SS & 4 & Strongly Agree & $S$ & 1 \\
\hline & & & & S & \\
\hline Agree & $S$ & 3 & Agree & $\bar{S}$ & 2 \\
\hline \multirow[t]{2}{*}{ Disagree } & TS & 2 & Disagree & $\mathrm{T}$ & 3 \\
\hline & & & & $S$ & \\
\hline Strongly Disagree & STS & 1 & Strongly Disagree & $\mathrm{T}$ & 4 \\
\hline
\end{tabular}

Source: Sugiyono (2012)

\section{Data Analyzes}

This study used descriptive and Partial Least Square (PLS) statistical data analysis with the help of SmartPLS 3.0 software. Using SEM analysis make it easier for to see effect and relationship of each variable that form construct or indicator( Mustofa, Riani \& Wardani, 2018). There are reasons for using PLS-SEM in this study as follows: (a) PLS-SEM is a general method for estimating the path model that uses latent variables with several indicators. (b) PLS-SEM is an analytical method that can be applied to all data scales, does not require many assumptions and the sample size does not have to be large, the recommended sample size ranges from 30 to 100 in this study the sample size are 67 respondents. (c) PLS-SEM is an analytical method for causal predicative analysis in situations of high complexity and low theoretical support. The model of this research can be seen from the following picture:

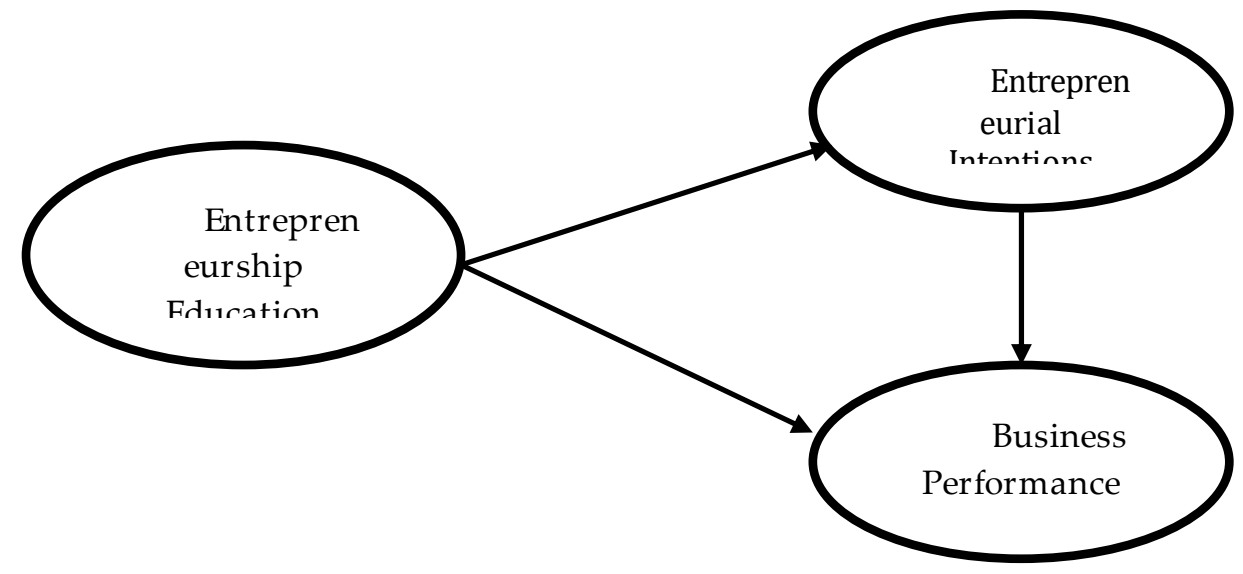

Picture 1 Research Model 


\section{FINDING}

\section{Evaluation and Measurement Model}

\section{Construct Validity}

The research questionnaire can be said valid or can use in research if the value of lading factor is more than 0,7 . Construct validity test parameter in the measurement model using reflexive indicators so that the value of Loading Factor between 0,5-0,6 can still be used (Yamin and Kurniawan, 2011; Haryono, 2017). The construct used in this study is 0,5-0,6 LF. After testing the contract validity, the result of the research questionnaire was said to be valid

\section{Construct reliability}

Reliability testing is done to prove the accuracy of the consistency and determination o the instrument in measuring construct. Evaluation of the value of construct reliability can be measured by composite reliable, Cronbach's alpha, AVE value (Average Variance Extracted) and comparing the AVE root value with the correlation between the constructs. If the value is $\geq 0,7$, the it is acceptable. AVE value are used to explain convergent validity. If the AVE root value is greater than the constructed correlation value, the discriminant validity requirements are met.

Table 5. Composite Reliability, Cronbach's alpha, AVE and AVE root

\begin{tabular}{lllll}
\hline Construct & $\begin{array}{l}\text { Composite } \\
\text { reliability }\end{array}$ & $\begin{array}{l}\text { Cronbach's } \\
\text { alpha }\end{array}$ & AVE & AVEroots \\
\hline $\mathrm{EE}$ & 0.980 & 0.977 & 0.862 & 0.928 \\
\hline $\mathrm{EI}$ & 0.985 & 0.983 & 0.787 & 0.937 \\
\hline $\mathrm{BP}$ & 0.978 & 0.974 & 0.848 & 0.928 \\
\hline
\end{tabular}

Source: data processed, 2018

Table 6. LatentVariable Correlation

\begin{tabular}{llll}
\hline Construct & EE & El & BP \\
\hline EE & 1.000 & ----- & ------ \\
\hline EI & 0.769 & 1.000 & ------ \\
\hline BP & 0.834 & 0.903 & 1.000
\end{tabular}

Source: data processed, 2018

Based on table 5 show that the value of composite and Cronbach'salpha is $\geq 0,7$ so that requirements for construct reliability is fulfilled. Furthermore, comparing the AVE root value with the latent correlation variable in table6. From this comparison, it is known that the AVE root value is greater than the correlation value between constructs in the model, so the discrimination validity requirements are met.

\section{Evaluation of the model (inner model)}

At the evaluation stage the structural model will be analyzed using a significant relationship between constructs indicated by the t-statistical value. Significant between value constructs can be seen in table 7.

Table 7. Path Coefficient

\begin{tabular}{llllll}
\hline & $\begin{array}{l}\text { Orginal } \\
\text { Sample (O) }\end{array}$ & $\begin{array}{l}\text { Simple } \\
\text { Mean (M) }\end{array}$ & StandarDevitation & T-Statistic & P-Value \\
\hline EE->EI & 0.276 & 0.256 & 0.129 & 2.334 & 0.020 \\
\hline EE -> BP & 0.235 & 0.226 & 0.079 & 2.960 & 0.004 \\
\hline EI -> BP & 0.323 & 0.323 & 0.156 & 2.072 & 0.039 \\
\hline
\end{tabular}


Source: data processed, 2018

The influence of entrepreneurship education on entrepreneurial intention.

Based on table 7, it is known that the path between the variables of entrepreneurship education and entrepreneurial intentions having an original sample value of 0.269 and $t$-value of $2.427>1.96$. These results indicate that entrepreneurship education variables have a positive and significant influence on entrepreneurial intentions.

The influence of entrepreneurial education on business performance.

Based on table 7, it is known that the path between the variables of entrepreneurial education and business performance has an original sample value of 0.235 and $t$-value of $2.960>1.96$. These results indicate that entrepreneurship education variables have a positive and significant in fluence on business performance.

\section{The influence of entrepreneurial intention on businessperformance}

Based on table 7, it is known that the path between entrepreneurial intentions and business performance has an original sample value of 0.323 and $t$-value of $2.072>1.96$. These results indicate that entrepreneurial intentions have a positive and significant influence on business performance.

\section{Mediation Effect}

Mediation effects are carried out to test the third research hypothesis. The mediating effect shows the relationship between exogenous variables and endogenous variables through connecting or mediating variables. Mediation effects are tested when it is assumed that ther e are mediating variables between exogenous variables and endogenous variables.

Thus the total effect output is used to see the total predictive effect (direct and indirect effect). Testing of mediation effects follows the Baron and Kennery rules, namely mediation effects can be done if the main effect (direct relationship) between the exogenous variables on endogenous variables is significant. The total effect of this research can be seen in table 7 .

Table 8. Total Effect

\begin{tabular}{llllll}
\hline & $\begin{array}{l}\text { Orginal } \\
\text { sample (O) }\end{array}$ & $\begin{array}{l}\text { Simple } \\
(\mathbf{M})\end{array}$ & $\begin{array}{l}\text { Standar } \\
\text { Deviation }\end{array}$ & T-Statistic & P-Value \\
\hline EE -> El & 0.276 & 0.256 & 0.129 & 2.136 & 0.033 \\
\hline EE-> BP & 0.324 & 0.314 & 0.094 & 3.443 & 0.001 \\
\hline El -> BP & 0.323 & 0.323 & 0.156 & 2.072 & 0.039 \\
\hline
\end{tabular}

Source: data processed, 2018

Based on the results of testing the structural model, the value of the Path Coefficients shows the following paths:

Entrepreneurial Education variables with business performance have a significant effect (3.443> 1.96). This shows that testing of mediation effects can be continued. In table 8 shows the mediating effects that can be seen through $\mathrm{t}$-statistics on entrepreneurship education variables on entrepreneurial intentions of 2.136> 1.96. This shows that entrepreneurial intention mediates in full (full mediation) the influence of entrepreneurship education on business performance. The magnitude of the mediation effect Entrepreneurship Education $->$ Entrepreneurial Intention $->$ Business Performance $=0.276 \times 0.324=$ 0.089 .

The influence of entrepreneurship education on business performance through entrepreneurial intention.

The test results show that the entrepreneurship education variable shows the value of indirect influence of 0.089 . The results show that entrepreneurship education influences business performance through entrepreneurial intentions. 
Amaliawati,S., Martono,T. \& Indrawati,C.D.S. (2019).The influence of entrepreneurship education on the business performance through entrepreneurial intention. International Journal of Educational Research Review,4(2),162-171.

\section{DISCUSSION AND SUGGESTION}

\section{Discussion}

This study examines the influence of entrepreneurship education variables (exogenous), entrepreneurial intentions (mediation) and business performance (endogenous). Based on the results of testing the hypothesis that has been done, found several findings in this study. The results are as follows:

First, the influence of entrepreneurship education on entrepreneurial intentions. The test results show that entrepreneurship education variables have a positive and significant effect on entrepreneurial intentions. Benefits of positive predictions (original sample, 0.276) which indicate that when entrepreneurship education is high, the intention of entrepreneurship is high. The parameter value is significantly high at 0.276 ( $\mathrm{t}$-value $2.136>1.96$ ) which means that education significantly influences the intention of entrepreneurship. This is in line with the disclosure of Lestari and Wijaya (2012) which states that entrepreneurship education can shape a person's mindset, attitudes and behavior to become a true entrepreneur so that they lead to choosing entrepreneurship into their career. According to Alhaji (2015) entrepreneurship education is an important component and provides a stimulus for individuals making career choices, thereby increasing the creation of new businesses and economic growth. Research conducted by Husein, Alfa and Norasidah (2015) concluded that education has a positive and significant effect on entrepreneurial intentions. Similar results are also shown by research conducted by Siswoyo, 2011; Aprilianti, 2012; Hendriyani, 2013; Nursito, 2013; Zegeye, 2013; Fatoki, 2014; Malebana, 2014; Bae, Qian, Miao and Fiet, 2014; Fayolle and Gailly, 2013.

Second, the influence of entrepreneurship education on business performance. The test results show that entrepreneurship education variables have a positive and significant effect on business performance. The nature of positive predictions (orginal sample 0.235) which shows that when entrepreneurship education is high, business per formance is also high. The parameter value is 2,960 ( $t$-value2.960>1.96) which means that entrepreneurship education significantly influences business performance. This is in line with the results of the Tendai study (2012) stated that entrepreneurship education has a positive influence on business performance. According to PacoFereria, Raposo and Radriges, (2015) through sufficient entrepreneurship education, one acquires the skills and knowledge needed to build and develop a business. In line with the research conducted by Hisrich, Petter and Shepherd (2008) stated that entrepreneurship education can improve the skills of managers and business owners. Other supporting opinions were also conveyed by Nieman and Nieuwenhuizen (2009) \& Daroch and Clover (2005) who argue that education through the development of entrepreneurial skills and knowledge has a positive impact on the survival and success of MSMEs. Through entrepreneurship education, MSMEs people can maintain their business performance (Peterman and Kennedy, 2003; Fayolle, 2006; Soutaris, 2007 and Graevenitz, 2010).

Third, the influence of entrepreneurial intentions on business performance. The results of the test show that the entrepreneurial intention variable has a positive and significant influence on business performance. The nature of positive predictions (original sample 0.323) which shows that entrepreneurial intention is high, business performance is also high. The parameter value is significantly high 2.072 ( $t$-value $2.072>1.96$ ) which means that entrepreneurial intentions significantly influence business performance. This is consistent with the research conducted by Radhipere and Ladzoni (2014) which states that entrepreneurial intentions have a positive and significant influence on business performance. According to Radhipere and Ladzoni (2014) entrepreneurial intention is qualified as the most powerful predictor of business performance. Entrepreneurial intentions have an important role in directing one's actions by connecting considerations that are believed to be desirable by someone. Entrepreneurs who have high entrepreneurial intentions will be able to maintain and develop their business compared to those who have no entrepreneurial intention remembering the many obstacles faced in the busin ess world (Farrington, Venter and Neething, 2012).

Fourth, the influence of entrepreneurship education on business performance through entrepreneurial intensions. The test results show there is an influence of entrepreneurship education on business performance through entrepreneurial intentions. This is because after testing the mediation effect using PLS-SEM it is found that the mediation results in this relationship are full mediation because the entrepreneurial intention variable mediates the relationship between entrepreneurship education and 
business performance. This condition is indicated by when MSMEs people having high and low entrepreneurship education will have an influence on business performance if they have entrepreneurial intentions. According to Hattab (2014) and Franke and Lutjhe (2004) entrepreneurship education has a role in encouraging one's entrepreneurial intentions. This statement is in line with Lestari and Wijaya (2012) who stated that entrepreneurship education can shape people's mindsets, attitudes and behaviors to become a true entrepreneur so they direct them to choose a career as entrepreneurs. According to Alhaji (2015) entrepreneurship education is an important component and provides a stimulus for individuals to make careers, thereby increasing the creation of new businesses and economic growth. Entrepreneurial intention has a positive and significant influence on business performance and qualifies as a strong business predicator (Radhipere and Ladzoni, 2014). Through the entrepreneurial intention, MSMEs players can maintain the viability of their business given the tight competition in the business world so that they need high entrepreneurial intentions to survive. So from the statement above it can be said that entrepreneurship education has an influence on business performance through entrepreneurial intentions.

\section{Suggestion}

Based on the results of testing in this study, some suggestions can be given. First, seeing the importance of entrepreneurship education for the continuity of business performance. It is expected that MSMEs players will take part in entrepreneurship seminars, entrepreneurship training, entrepreneurial talk shows held by the government or other institutions to obtain entrepreneurship education so that they can add insight into entrepreneurship, increase skills and knowledge in managing MSMEs. Second, the government is expected to participate in improving the quality of the performance of MSMEs people. Government support can be in the form of organizing training, entrepreneurship and entrepreneurial talk shows to help MSMEs people gain knowledge and skills in entrepreneurship so as to help them manage their business. Third, looking at the important role of entrepreneurship education, universities and high schools / vocational schools as places to create competent young entrepreneurs, are expected to be able to provide entrepreneurship education learning with material that is easy to understand and interesting so that it can encourage students' intention to become entrepreneurs. In addition, it is also expected to be able to carry out entrepreneurial practices involving students so that students have a real picture of the world of entrepreneurship, not just theory. Fourth, the variables used in this study are still limited to only entrepreneurship education variables and entrepreneurial intentions as factors that influence business performance. Therefore, the next researcher is expected to add other variables related to business performance. So that it can provide a broader picture regarding what factors can affect business performance.

\section{Limitation}

The research has been attempted and carried out in accordance with scientific procedures, but still has limitation:

1. Factors that influence business performance are still limited to 2 variables that are entrepreneurship education and entrepreneurial intention, while there are still many other factors that influence business performance.

2. There are limited costs so that the researcher can only do research at MSMEs Batik Laweyan. Even though there are still many MSMEs Batik besides Laweyan.

3. There is limited research by using questionnaires so that sometimes the answers given by respondents are not in accordance with the actual situation.

\section{REFERENCES}

Aprillianti, Eka. (2012). Pengaruh kepribadian wirausaha, pengetahuan kewirausahaan dan lingkungan terhadap niat berwiraushasisw a SMK. Jurnal Pendidikan Vokasi, 2(3), pp.311-324.

Bae, T. J., Qian S., Miao, C., \& Fiet, J. O. (2014). The Relationship Between Entrepreneurship Education and Entrepreneurial Intentions: A Meta-Analytic Review. Entrepreneurship: Theory \& Practice, 38 (2), 217-254.

Cheng, M.Y., Chan, W.S., \& Mahmood, A. (209). The effectiveness of entrepreneurship education in Malysia. Education + Training 51 (7), pp. 555-566. 
Amaliawati,S., Martono,T. \& Indrawati,C.D.S. (2019). The influence of entrepreneurship education on the business performance through entrepreneurial intention. International Journal of Educational Research Review,4(2),162-171.

Clover, T.A., \& Darroch, M.A.G. (2005). Owner's perceptions of factors that constrain the survival and growth of small, medium and micro agribusinesses in Kwa Zulu Natal, South Africa. Journal Agrekon, $44(2), p p .238-26$.

Enu, D.B. (2012). Enhancing the Entrepreneurship Education in Nigeria. American Journal of Social Issue $\mathcal{E}$ Humanities, Vol.2(4)pp. 232-239.

Farrington, S.M., Venter, D.J.L., \& Neethling, A. (2012). Entrepreneurial attributes and intention: perceptions of Shouth African business science students. Management Dynamics. Vol (3), pp.17-32.

Fatoki, Olawle. (2014). The Enterpreneurial Intention of Undergraduate Student in South Africa: The Influences of Enterpreneurship Education and Previous Work Experience. Mediterranean Journal of Social Sciences, 5(7), pp. 294-299.

Fayolle, A., \& Gailly, B. (2013). The Impact of Entrepreneurship Education on Entrepreneurial Attitudes and Intenttion: Hyesteresis and Persistence. Journal of Small Bussiness Management, 53 (1), pp.75-93.

Fayolle, A., \& Gailly, B., \& Lass Clerc, N. (2006). Assesssing the impact of entrepreneurship education programmes: a new methodology. Journal of Europen Industrial Training, 30(9), pp.701-720.

Franke, N., \& Lutjhe. (2004). Entrepreneurial Intentios of Bussines Students: a Benchmarking Study. International Journal of Innovation and Technology Management Dynamic. Vol 3, pp.17-32.

Gibb, A. \& Li, J. (2003). Organizing for enterprise in China: what can we learn from the Chinese micro, small, and medium enterprise development experience. Futures, 30(4), pp.403-21.

Gimeno, J., Folta, T., Cooper, A. \& Woo, C. (1997). Survival of the fittest? Entrepreneurial human capital and the persistence of underperforming firms. Administrative Science Quaterly, vol.42, pp. 750-783.

Graevenitz, G. V., Harfof, D., \& Weber, R. (2010). The Effect of Entrepreneurship Education. Journal of Economic Behavior and Organazitation, 76 (1), pp. 90-112

Haryono, Siswoyo. (2007). Metode SEM untuk Penelitian dengan AMOS 22.00. LISREL 8.80 dan SMART-PLS 3.0. Jakarta Timur: Luxima Metro Media, PP. 5-113. ISBN 978-602-268-176-2.

Hattab, H.W. (2014). Impact of Enterpreneurship Education on Entrepeneurial Intentions of University Students in Egypt. The Journal of Enterpreneurship Vol 23, Issue 1, pp.1-18

Hisrich, R.D., Petters, M.P. \& Shepherd, A. (2010). Entrepreuneurship. $8^{\text {th }}$ Edition, USA. McGraw Hill.

Hussain, Alfa dan Norashidah. (2015). Impact of Enterpreneurial Education on Entrepreneurial Intention of Pakistan Students. Journal Entrepreneurship and Business Inovation. Vol. 2 (1), pp.43.53.

Iyola, O. \& Azuh, D. (2014). Women Enterpreneurs as Small-Medium Entreprise (SME) Operators and thir Roles in Socio-Economic Devlopment In Ota, Nigria. International Journal of Economic, Bussines and Finance, Vol. 2, pp.1-10.

Lestari, R.B \& Wijaya, T. (2012). Pengaruh Pendidikan Kewirausahaan Terhadap Minat Berwirausaha Mahasisiw a di STIE MDP, STMIK MDP dan STIE MUSI. Jurnal Ilmiah STIE MDP, Vol.8(1), pp.112-119.

Lumpkin, G. T., \& Dess, G. G. (1996). Clarifying the Entrepeneurial Orientation Construct and Linking it to Performance. The Accademy of Management Review Vol 21 (1) pp. 135-172 
Amaliawati,S., Martono,T. \& Indrawati,C.D.S. (2019).The influence of entrepreneurship education on the business performance through entrepreneurial intention. International Journal of Educational Research Review,4(2),162-171.

Malebana, J. 2014. Entrepreneurship Intentions South African Rural Univesity Student: A Test of the Theory Planned Behavior. Journal of Economics and Behavioral Studies, Vol.6 No.2, pp. 130-143.

Mustofa, R.H., Riani, A.L., \& Wardani, D.K. (2018). The Impact of Police: How Scientific Publication Police and Socio-Economics Status Affect Motivation and Types of Publication Among Gratuate Students. International Journal of Educational Reserch Review, 4(2), pp.1-12.

Nieman, G., \& Niuwenhuzen, C. (2009). Enterpreunership: A South African Perpective. Petorial : Van Schaik.

Paco, A.M.F., Ferreira, J.J.M., Raposo, M., \& Rodrigues, R.G. (2015). Entrepeneurial Intentions: Is Education Enough?.International Entrepeneurship and Management Journal, Vol.11(1), pp. 57-75.

Peterman, N. E., \& Kenndy, J. (2003). Enterprise Education: Influencing Student's Perception of Entrepreneurship. Entrepreneurship Theory and Pratice, vol. 28(2), pp.129-144.

Rina, L., Murtini, W., \& Indriayu, M. (2018). Estaible of Entrepreneurial Character in the Foundation based School System through Project Based Learning. International Journal of Education Research Review, Vol 3(4), pp.128-140.

Riyanti, B.P.D. (2003). Kewiraushaan Dipadandang dari Sudut Pandang Psikologi Kepribadian. Penerbit PT Grasindo: Jakarta.

Silvia. (2013). Pengaruh Enterpreneurial Trait dan Entrepreneurial Skill TrhadapIntensi Kewirausahaan (Studi Empiris Dampak Pendidikan Kewirausahaan pada Mahasiswa Universitas Kristen Petra, Surabaya). AGORA, 33(2), pp. 142-159.

Souitaris, V., Zerbinati, S., Andreas, A.L. (2007). Do Entrepreneurship Programmes Raise Entrepreneurial Intention of Science and Engineering Student? The Effect of Learning, Inspriration and Resources. Journal of Business Venturing, Vol. 22 No. 4, pp. 556-591.

Sugiyono. (2013). Metode Penelitian Kuantitatif, Kualitatifdan RED. Bandung: Alfabeta.

Suryana. (2006). Kewirausahaan Pedoman Praktis: Kiat dan Proses Menuju Sukses. Edisi Ketiga. Jakarta: Salemba.

Tarmudji, Tarsis. (1996). Prinsip-Prinsip Kewirausahaan. Yogyakarta: Liberti.

Winklund. J., \& Shepherd. D.(2005). Entrepeneurial orientation and small business performance: a configurational approach. Journal Of Bussiness Venturing, Vol. 20(1), pp.71-91.

Yamin, S. \& Kurniawan, H. (2011). Generasi Baru Mengolah Data Penelitian dengn Partial Least Square Path Modeling. Jakarta: Salemba Empat.

Yuwono, Susatyo. (2003). Peranan Unversitas dalam Memotivasi Sarjana Menjadi Young Entrepreneur. Jurnal Manajemen E Kewirausahaan, Vol 5(2), pp.97-111.

Zaenal, Abdul. (2012). UMKM Sebagai Tulang Punggung Perekonomian Nasional. Bandung: Alabeta.

Zegeye, Buzeye. (2013). Factors Explaining Student's Inclination tow ords Entrepreneurship: Empirical Study of Ethiopian Uniersity Students. Journal of Emerging Issue in Ecconomic, Finanace and Baking, vol. 1(14), pp.302:320.

Zimmerer, Thomas. W. \& Norman, Scarborough. (2004). Pengantar Kewirausahaan E Manajemen Bisnis Kecil. Gramedia: Jakarta. 